\title{
Kirkelig undervisning - hva nå? Utfordringer med religionsmangfold og lav deltakelse
}

\author{
Av Erling Birkedal, Heid Leganger-Krogstad og \\ Hans Austnaberg
}

Når dette skrives, er det snart 15 år siden trosoppleringsreformen ble vedtatt i Stortinget. Tiden er inne til å spørre om reformen har innfridd de mål og forventninger som var ved oppstarten, og hva som er veien videre. ${ }^{1}$ Vi vil i denne artikkelen reflektere over noen av utfordringene vi ser. For det første har vi i langt større grad fått et flerreligiøst/religionsmangfoldig samfunn. Barn og unge møter gjennom skolen, og særlig KRLE-undervisningen, religionsmangfoldet $i$ direkte eller indirekte forstand. Kirken kan ikke forutsette at barna som kommer til trosopplering, har et innenfrablikk på kristendom gjennom skolens undervisning eller hjemmefra. For det andre er omfanget av kristendomsundervisning for barn og unge blitt mindre, også for de som blir døpt. Trosoppleringsreformen skulle gi opplering til alle døpte. Tallenes tale er imidlertid tydelig: om lag en fjerdedel er med på trosopplæringstiltak før konfirmasjonstiden. Majoriteten av de døpte er ikke med $i$ en systematisk opplæring fra småbarnsalderen. Trosopplering skulle erstatte bortfall av rundt 300 timer kristendomsundervisning i skolen. Det har altså for de fleste ikke skjedd. På bakgrunn av utviklingen de siste ti-årene vil vi reflektere over konsekvensene av at barna lever i en flerreligiøs kontekst, og utfordringen med kirkelig undervisning for alle døpte. Vi spør hvordan kirken i enda større grad kan oppnå de gode mål og intensjoner som lå til grunn for trosopplaringsreformen.

\footnotetext{
ERLING BIRKEDAL, 1954, forsker og prosjektleder ved Det teologiske menighetsfakultet, Likollen 39, 1481 Hagan, erling.birkedal@mf.no

HeID LEGANGER-KROGSTAD, 1950, professor i religionspedagogikk ved Det teologiske menighetsfakultet, Sleiverudlia 32, 1354 Bærums Verk, Heid.Leganger-krogstad@mf.no

HANs AustNABERG, 1956, professor i praktisk teologi ved VID vitenskapelige høgskole, Haugtussavegen 6, 4344 Bryne, hans.austnaberg@vid.no
}

\section{MANGFOLD I SAMFUNN OG KIRKE}

Mobilitet og ny medievirkelighet gjør at møte med religionsmangfold berører skole, kirke, arbeidsplasser, hverdagsliv og fritid i økende grad. Religionsblandede familier kommer til dåp, konfirmasjon, vigsel og begravelser og utfordrer vante tenkemåter. Mangfoldet innen kristendommen kan oppleves st $ø$ rre ved at flere menigheter erfarer at immigranter oppsøker menigheten enkeltvis eller som

1 Se generell informasjon om reformen her: https://kirken.no/nb-NO/kristen-tro/trosopplaring/om-trosopplaring-i-den-norske-kirke/ [13. desember 2016] 
små språkmenigheter som vil låne kirkens lokaler. ${ }^{2}$ Barn og unge har gjennom skolen og særlig KRLE-undervisningen møtt religionsmangfoldet i direkte eller indirekte forstand. Det er stor variasjon blant de døpte barna med hensyn til erfaring med kristen religiøs praksis fra hjem og kirke. Kirken kan ikke forutsette at barna som kommer til trosopplæring, har erfaring med eller innsikt i kristen tro og praksis, et innenfrablikk. Vi vil derfor trekke veksler på et teoretisk perspektiv som er utviklet for å håndtere det religiøse mangfold i samfunnet og innlemme mennesker i samfunnet som helhet.

Det ble utviklet en teoretisk basis for flerkulturell undervisning generelt $\mathrm{i}$ møte med det flerreligiøse samfunn på 1980-90-tallet. Tanken var at det måtte skapes et visst verdifellesskap mellom alle i samfunnet, men at det er ulike interessefellesskap i form av ulike delkulturer. Pedagog Tor Ola Engen omtalte dette som teori om dobbeltkvalifisering og integrerende sosialisering. ${ }^{3}$ Denne tenkningen la også noe av grunnlaget for utformingen av KRL-faget på 1990tallet. ${ }^{4}$ Det var et pedagogisk svar på religionsmangfoldet i samfunnet. I skolen skal en ta utgangspunkt i barns og unges egen kulturbakgrunn og erfaringer, og samtidig gi opplæring i samfunnets fellesverdier. Det gjelder å styrke egen identitet og samtidig være $\mathrm{i}$ åpen dialog med ulike posisjoner og tradisjoner $\mathrm{i}$ samfunnet, for å gi dobbeltkvalifisering. Dette perspektivet innebærer en anerkjennelse av barns tilhørighet i ulike kulturer, religioner og livssyn, samtidig som de skal få en opplæring eller sosialisering inn i det flerkulturelle og flerreligiøse samfunn. ${ }^{5}$ Dobbeltkvalifiseringen gjelder uavhengig av om eleven tilhører en minoritetskultur eller en majoritetskultur. Minoriteter trenger å styrkes i sitt eget samtidig som de gis gode kunnskaper i å forstå majoritetskulturen for å få nøkler til å forstå storsamfunnet. ${ }^{6}$ Majoritetsbarna skal også styrkes i sin identitet og gis kunnskap for å håndtere mangfoldet, altså kunnskap om minoritetene i Norge.

Den ovennevnte teorien anvendes vanligvis på samfunnet som helhet. Når vi nå også anvender dette overfor Den norske kirke (Dnk), gjør vi det med visse modifikasjoner. Det er ikke et religiøst mangfold i kirken i den forstand at medlemmer tilhører andre registrerte religioner eller trossamfunn. Samtidig erkjenner vi at det er et religiøst mangfold innen kirken med hensyn til hold-

2 Problemstillingen drøftes ikke her. Vi henviser til: Wanjiru, Margaret Wangari. (2013). The role of immigrant churches in the incorporation of their participants to the broader norwegian society. (Masteravhandling $\mathrm{i} \ll$ Religion, Society and Global issues»), Det teologiske menighetsfakultet, Oslo. Aschim, Anders, Sødal, Helje Kringlebotn, \& Hovdelien, Olav (Eds.). 2016. Kristne migranter i norden. Kristiansand: Portal

3 Se presentasjon av dette i NOU 1995: 12 Opplaring i et flerkulturelt Norge og Engen 1989 og 1994.

4 Identitet og dialog. NOU 1995:9. Peder Gravem har beskrevet teorien om integrerende sosialisering på en utfyllende måte knyttet til KRL-faget i grunnskolen. Gravem 2004

5 Anvendelse av teorien om dobbeltkvalifisering er spesielt gjort av forskere knyttet til Høgskolen i Hedmark, der Tor Ola Engen også var ansatt. Se blant annet antologi utgitt i forbindelsen med Engens 70-årsdag, Dobson, Kulbrandstad, Sand, \& Skrefsrud 2015.

6 Dette skal gi konkurranselikhet i relasjon til sosial mobilisering i samfunnet. Se Leganger-Krogstad 2011. 
ning, engasjement og praksis. ${ }^{7}$ Folkekirken er pluralistisk innen sine rammer. En kan ikke si at en juridisk tilhørighet til kirken (medlemskap) er det samme som en kulturell eller teologisk tilslutning, eller at alle medlemmer har erfaring med en bestemt religiøs praksis. Majoriteten i det norske samfunnet som tilhører Dnk, har heller ikke fătt opplæring eller delaktighet i slik praksis, ved at jevnt over en fjerdedel følger kirkens trosopplæring. De får også en mangelfull kvalifisering til å forstå kristendom og føle tilhørighet til denne gjennom skolens flerreligiøse, orienterende undervisning. Samtidig er det de som har en slik praksiserfaring, som kan oppleve seg som minoritet i majoriteten som tilhører samme trossamfunn. ${ }^{8}$ Dobbeltkvalifiseringen anvendt på kirken innebærer at også majoritetsmedlemmene har behov for å etablere et innenfrablikk på kulturen de formelt tilhører. Et slikt innenfrablikk forutsetter erfaring med å ta del i kristen høytidsfeiring, forstå kristendommens virkningshistorie i vestlig kultur, kjenne den kristne grunnfortelling og bekjennelse og prøve ut og gjøre erfaringer med praksisene som tilhører den kristne religionen. Når kristne praksiser ikke lenger er skolens oppgave, må det få konsekvenser for kirkens undervisning.

Vi omtaler altså dobbeltkvalifisering på to nivå, på samfunnet som helhet, og innen en gruppe, Den norske kirke. På samfunnsnivå har integrering i form av dobbeltkvalifisering som mål å kunne beherske både egen kultur og storsamfunnets kultur, i samspill med også andre religiøse grupper. Her har Dnk ansvar for å bidra til å gjøre kristen kultur og kunnskap tilgjengelig for alle mangfoldsamfunnets medlemmer ved å gi innsyn i den evangelisk lutherske arven, som har satt sitt preg på norsk kultur gjennom 500 år. Gjennom kunnskap til majoritetssamfunnets kultur og konvensjoner åpnes adgangen til majoritetssamfunnet. På gruppenivå (kirken) kan målet med dobbeltkvalifisering forstås som å kunne beherske både egen lokal kultur (familiens tradisjon og evt. gruppetilhørighet i religiøs forening $\mathrm{mm}$ ) og folkekirkens kultur. Vi tenker at de døpte medlemmer av Dnk skal få del i en dobbeltkvalifisering både på gruppenivå og samfunnsnivå. Nedenfor vil vi belyse dette nærmere ved å se på endringene i relasjonen mellom kirke og skole.

\section{EN SKISSE AV UTVIKLINGEN FRA 1980-TALLET}

For å se situasjonen i dag og mulige endringer for fremtiden i et lengdeperspektiv, vil vi først ta et kort tilbakeblikk.

Skoleloven av 1969 hadde et tydelig kristent og humanistisk verdigrunnlag

7 Se f.eks. Birkedal 2015.

8 Elever som kommer fra praktiserende kristne familier, kan føle seg som minoriteter i skolen. Se f.eks. uttalelse om å være kristen på skolen, fra Ungdomstinget i Stavanger bispedømme fra 2017: https://kirken.no/nb-NO/ bispedommer/stavanger/om-bispedomme/ungdom/ungdomsting/ [sett 10.08.17] 
for grunnskolen. ${ }^{9}$ Verdiformuleringene og undervisningsplanen i kristendomskunnskap la grunnlag for en nær kontakt og samarbeid mellom skolen og kirken, og skolens kristendomsfag ga i praksis en undervisning som støttet opp om majoriteten, den lutherske kirkens intensjon og mål, selv om den ikke lenger var del av kirkens dåpsopplæring..$^{10}$ Samfunnet på 1980-tallet var preget av et $\emptyset$ kende mangfold med hensyn til religioner og livssyn. Mangfoldet ble etter hvert spesielt merkbart i skolens religionsundervisning. ${ }^{11}$ Det ble en debatt om hvorvidt det tradisjonelle kristendomsfaget fungerte som en uheldig form for assimilering for enkelte, og i Mønsterplanen av 1987 ble det gjennomslag for en $\emptyset$ kende parallellundervisning med rom for alternative undervisningsplaner for elever som ikke var medlemmer av Dnk. ${ }^{12}$ Religionsundervisningen i skolen er begrunnet $\mathrm{i}$ foreldrenes mandat til å bestemme religiøs undervisning for sine barn, menneskerettighetene og $\mathrm{i}$ barns behov for åndelig utvikling.

I løpet av 1970- og 1980-tallet ble det gradvis en økende bevissthet om at kirken måtte ta ansvar for opplæring av de døpte, i tillegg til skolens undervisning og konfirmantundervisningen. ${ }^{13}$ Tidlig på 1980-tallet ble det tatt initiativ til et relativt omfattende opplæringsprogram for døpte barn til bruk i hjemmet, og det ble utviklet utkast til plan for dåpsopplæring. ${ }^{14}$ Etter en fors $\emptyset$ ksperiode på siste del av 1980-tallet ble en slik plan vedtatt på Kirkemøtet i 1991.15

Endringer fra 1990-tallet kan i korthet beskrives som en utvikling fra gruppedelt religionsundervisning innenfor egen tradisjon til en felles flerreligiøs undervisning i skolen og en ytterligere styrking av trossamfunnenes egen trosopplæring.

Innføring av KRL-faget fra 1997 var basert i tenkningen om integrerende sosialisering og dobbeltkvalifisering (se ovenfor). KRL-faget forutsatte en deling av ansvaret for opplæringen om og opplæringen $i$ religion. Skolen skulle lære elevene om religion for å kvalifisere dem til å leve sammen i et mangfoldssamfunn, mens

9 Det heter her at skolen skal gi «ei kristen og moralsk oppseding», og læreplanen som kom på 1980-tallet, sier at virksomheten skal baseres på «kristne og humanistiske verdier» (M87). Se nærmere omtale av formålsparagraf og verdigrunnlaget i skolen i f.eks. NOU 2007:7, Formål for framtida.

10 Allerede i 1969, i forbindelse med vedtak av ny skolelov, presiserte Stortingets kirke- og undervisningskomite at skolens kristendomsundervisning ikke var «dåpsopplæring i kirkelig forstand». Dette fikk imidlertid ikke direkte konsekvenser for innholdet i fagplanene, som fortsatt skulle være knyttet til «evangelisk-luthersk kristendom», og evt. fritak var for de som ikke var medlem i kirken/døpt. Se nærmere omtale av denne historien i for eksempel NOU 1995:9, Identitet og dialog, Kristendomskunnskap, livssynskunnskap og religionsundervisning, og i NOU 2000:26, «... til et åpent liv i tro og tillit». Dåpsopplaring i Den norske kirke.

11 Se Leganger-Krogstad, 2008 som redegjør for utviklingen av religionsfaget i grunnskolen.

12 Det var egen plan for livssynskunnskap og i tillegg mulighet for andre trossamfunn å lage egne planer for grupper av elever.

13 Daværende Institutt for Kristen Oppseding (IKO) utviklet et Undervisningsprogram for hjem og kirke (UPRO). Bispemøtet satte tidlig på 1980-tallet ned en arbeidsgruppe: Dåpspraksis og dåpsopplæring i Den norske kirke: en utredning avgitt til Bispemøtet våren 1982.

14 Se omtale av Hjemmenes Dåpsring i Evenshaug, Hallen og Riktor: Barnet $i$ våre hender. HD-forlaget 1986

15 Plan for dåpsopplering $i$ Den norske kirke, Kirkerådet 1992. 
hjem og trossamfunn skal oppdra og lære opp i og innenfor den religion eller det livssyn barnet tilhører. Dagens KRLE-fag er juridisk sett forpliktet til å presentere ulike verdensreligioner og livssyn på en objektiv, kritisk og pluralistisk måte, og undervisningen skal ikke være forkynnende (Opplæringsloven § 2-4). Religiøst mangfold og religiøse forskjeller mellom elevene i skolen berører mange fag som for eksempel norsk, samfunnskunnskap, kroppsøving og mat og helse. Religion i skolen er derfor både et fag og en dimensjon ved hele skolens virksomhet. Elevene utvikler gjennom skolen en dialogkompetanse, og de får kunnskap til å forstå begrunnelsene for ulike vaner, skikker og livsstiler blant elevene.

Omfanget av kristendomsundervisningen ble grovt sett halvert i KRL-faget, sett i forhold til tidligere kristendomsfag. ${ }^{16}$ Stortingets vedtak om reform av trosopplæringen i 2003, med $\emptyset$ konomisk støtte til både Dnk og andre trossamfunn basert på deres medlemstall, kan forstås på minst to måter: For det første er det en kompensasjon til Dnk for tap av kristendomsundervisning i skolen. For det andre er det en anerkjennelse og støtte til trossamfunnenes oppgave og funksjon i det mangfoldige samfunnet.

Noen av de sentrale målene i trosopplæringsreformen i Dnk er at trosopplæringen skal være systematisk og sammenhengende for alle døpte i alderen 0-18 år, med et retningsgivende omfang på 315 timer for hvert barn, og at trosopplæringens breddetiltak skal stå i samvirke med menighetens gudstjenesteliv, barne- og ungdomsarbeid og den formidling og trosutøvelse som skjer i hjemmene (Kirkerådet 2010: 10). Trosopplæringsreformen har ført til større omfang av undervisning i menighetene, og flere barn er involvert i kirkens undervisning enn det som var tilfellet før reformen. Det er imidlertid bare ca. $1 / 4$ av de døpte barna som følger kirkens trosopplæringsprogram, men variasjonen er relativt stor menighetene imellom. ${ }^{17}$ I noen menigheter er det også stor grad av kontinuerlig undervisningsarbeid, knyttet til ulike organisasjoner, mens det $\mathrm{i}$ andre menigheter er lite eller ingen ting av dette (Aagedal mfl 2014).

Selv om en på samfunnsnivå kan si at det er en flytting av kristendomsopplæring fra skolen til kirken, er det altså i praksis ikke tilfelle for alle på individnivå. De fleste døpte barna som tidligere fikk kristendomsundervisning $i$ skolen, får ikke en opplæring i kirken i tilsvarende omfang. Breddetiltak for alle døpte synes også å ha størst oppslutning i små menigheter (Botvar, Haakedal, \& Kinserdal, 2013). På grunnlag av denne situasjonsbeskrivelsen av trosopplæringen og rammene for kirkens/menighetens undervisning, vil vi konsentrere den videre drøftingen til to utvalgte tema: kirkelig undervisning i et flerreligiøst perspektiv og undervisning for alle døpte.

16 Se NOU 2000:26

17 Se nærmere om oppslutning i Botvar mfl 2013, kap. 4. Årsrapport for Den norske kirke 2015: Ca 3/4 av medlemmene i Dnk døper sine barn (s. 19). 25-30 \% av de døpte deltar på noen avgrensede tiltak mellom 4-årsalderen og konfirmasjonen (s. 22). 


\section{KiRKELIG UNDERVISNING I ET FLERRELIGIØST PERSPEKTIV}

Det norske samfunnet har som nevnt utviklet seg til å bli langt mer religiøst mangfoldig, og det ser ikke ut til at denne utviklingen vil reverseres i overskuelig framtid. I prosjektet vi redegjør for i Prismet 3/17, var en menighet på Østlandet mer preget av flerreligiøsitet enn de andre menighetene. ${ }^{18}$ Her sier presten blant annet: «Når de unge melder seg til kirkelig konfirmasjon, så har de bestemt seg for å være kristne. Det betyr at de går til nattverd med en gang». Dette utsagnet tolker vi dithen at ungdommer som lever med andre religioner nær seg, ser valg av kirkelig konfirmasjon som et valg mellom religioner, mer enn et valg mellom et religiøst eller sekulært standpunkt, slik konfirmanter ofte har tenkt tidligere. I det øyeblikk de melder seg til kirkelig konfirmasjon, tar de del i nattverd umiddelbart, fordi det er en del av den religiøse praksis som hører sammen med kristendom, slik de har forstått det. I KRLE lærer de at alle religioner har sine tilhørende praksiser, og da synes det som om ungdommene forventer å delta $\mathrm{i}$ en slik praksis når de kommer til konfirmantopplæringen. Nattverden skifter karakter fra å være en indikator, i en monoreligiøs sammenheng, på hvor overbevist eller bekjennende kristen man er, til, i en flerreligiøs setting, å være en av praksisformene som tilhører den kristne religionen. Graden av tilslutning til denne religionen blir da mindre relevant. Kateketen i samme menighet sier: $\ll$ Muslimer har mer religionsstolthet enn de kristne. De kristne opplever seg som minoritet selv om de er majoritet.» Vi tolker henne slik at hun her mener at ungdommene tilhørende den kristne religionen trenger kirkelig undervisning som gir både språk om og erfaring med praksiser, som kan bidra til å trygge deres identitet som kristne i møte med annen religiøs tro og praksis.

Fra andre menigheter i mer monoreligiøse områder hører vi at en stor utfordring i kirkens undervisning beskrives som konkurranse med andre gode formål, altså fritidsaktiviteter. Det er kamp om tiden. Det dreier seg da ikke primært om identitetsbygging og tilhørighet. Kirkens ansatte bruker her heller fritidssektorens retorikk og innretter seg i et konkurrerende marked. I menigheten i det flerreligiøse lokalsamfunnet kan derimot menighetens ansatte bli involvert i relativt omfattende religionsdialog, særlig muslimsk-kristen dialog. Presten fra samme menighet på Østlandet sier at slik dialog har blitt særlig nødvendig da en har erfaring med at muslimsk ungdom fra lokalsamfunnet har latt seg verve som fremmedkrigere. Kirkens rolle i lokalsamfunnet har da ikke kun karakter av en økumenisk samtale mellom ulike kristne trossamfunn og organisasjoner, men er en dialog på tvers av religioner. Språket i disse dialogene må nødvendigvis bli ulik den $\emptyset$ kumeniske samtalen. Den $\emptyset$ kumeniske samtalen kan regnes som ledd i intern integrering, mens religionsdialogen er ledd i den eksterne integreringen.

18 Se nærmere omtale av materiale i Austanberg 2017, Austnaberg og Birkedal 2017, Birkedal og Austnaberg 2017, Birkedal 2017, Leganger-Krogstad 2017. Menigheten vi omtaler her, er i disse artiklene omtalt som øB. 
Da gjelder det å bygge omdømme i storsamfunnet, slik denne presten sier: «Alt vi gjør for å bygge gode relasjoner i lokalmiljøet bygger også kirkens omdømme. Når en hører hva kirken gjør, vil det være flere som tenker at her $\emptyset$ nsker jeg at mitt barn skal være med». Han fortsetter: «Trosopplæringen er eneste sjansen vi har til å holde kunnskapsnivået om kristendom oppe».

Vi hører her at kirkens ansatte er seg bevisst at deres handlinger og presentasjonsformer representerer den kristne religion overfor omverden og overfor de som kommer til trosopplæring i kirken. De ansatte her er videre opptatt av at trosopplæring er å gi kunnskap om kristendom. Det er altså ikke bare udefinert kunnskap om tro, erfaring med å være skapt, et sunt ungdomsfellesskap eller gode verdier. Dette innebærer et utenfra-blikk på egen virksomhet som fordrer et språklig skifte som kan ligne den øvelsen lærere har vært gjennom fra de første jødiske eller muslimske elever entret norske klasserom, og som etter hvert er satt i system i religionsfaget (Leganger-Krogstad 2011). Kultur, eller det vi tar for gitt, måtte ordlegges for å bidra til minoritetenes inngang i det norske skolesystemet. Blant annet måtte en klargjøre hvor i samfunnet kristendom har satt spor i kultur, virkelighetsoppfatninger og i verdier. En slik omlegging som skolen har vært gjennom, i overgangen fra et monokulturelt samfunn til et flerreligiøst, får konsekvenser for hvordan kirken underviser sine egne medlemmer i kristen tro. Kirken forholder seg til barn med erfaring fra det flerreligiøse, og de må trygges i sitt eget samtidig som de må evne å presentere og forklare bakgrunnen sin eller troen sin i møte med barn med annen religions- eller livssynsbakgrunn. I skolen får de liten hjelp til å se hvordan kristendommen relaterer seg til og vurderer de andre synene. Særlig barn med svak kirkelig tilhørighet - den såkalt tause majoritet (Rudge 1998) - har behov for å få hjelp til å forstå sin egen kulturbakgrunn. Kirkelig undervisning får ved dette en ny rolle som identitetsskaper og folkeopplyser. En kirkelig undervisning i det flerreligiøse samfunn krever en dobbeltkvalifisering, både en opplæring i å se den kristne tradisjon i relasjon til storsamfunnet $o g$ en indrekirkelig opplæring.

Det er tilstrekkelig å ta en titt på Dnk's nettsider nasjonalt og lokalt for å se at en ikke er $\emptyset$ vet i selvpresentasjon i en flerreligiøs sammenheng. En føler seg lite forpliktet til å forklare hva luthersk kristendom er, og hva som kjennetegner religiøs tilhørighet og praksis innenfor denne religionen. Vi mener at dagens barn og unge har direkte og indirekte flerreligiøse erfaringer som krever en utvidelse og justering av (kristen) teologisk språkføring. Det kan et religionsvitenskapelig språk og perspektiv tilby. Kirkelig undervisning i en flerreligiøs kontekst må ta konsekvensen av at kristendom er en av flere religioner (Leganger-Krogstad 2010). Menigheter kan lære noe av skolen her. I skolen har man utviklet et bevisst referansesystem, nemlig at man stadig bruker referanser for å klargjøre innenfor hvilken logikk, filosofi, livssyn eller religion man ope- 
rerer: «Sunnimuslimer hevder ..., de fleste hinduer sier ..., ... hos sikher i Norge, norske jøder er ..., hjemvendte jøder i Israel ..., ifølge lutherske kirkers bekjennelsesskrifter ..., i kristen etikk ...» osv. Slike referanser er barn og unge som kommer til kirkelig undervisning, vant med. Men avstanden mellom skolens språk og kirkens språk er såpass stor at deltakerne i trosopplæringen får liten hjelp til å navigere i et flerreligiøst landskap (Holmqvist 2014). Dette flerreligiøse perspektivet innebærer behov for en mer utviklet religionsteologi i norsk sammenheng. Her vil vi anta at kunnskap fra misjonsvitenskap kan komme til god nytte også her hjemme.

Ledere ved moskeer og templer rundt omkring i landet er vant til å stå fram som representanter for sin religion, og er åpne for å drive utstrakt opplysningsarbeid. Ekskursjoner av ulike slag fra skoler er vanlig. De blir også stadig opps $\emptyset$ kt av elever som skal svare på skoleoppgaver, og de har opplysningsavdelinger. Før trosopplæringsreformen ivaretok kirken i langt st $ø$ rre grad denne opplysningsvirksomheten, gjennom et samarbeid mellom kirke og skole. I løpet av reform av trosopplæringen er dette arbeidet blitt nedprioritert. I lys av teorien om dobbeltkvalifisering og integrerende sosialisering ser vi at særlig to grupper elever taper på dette. For det første er det de som tilhører Dnk, men som uteblir fra trosopplæringstiltak helt fram til konfirmasjonsalder. Dernest er det elever som tilhører minoritetskulturer, enten det er kristne trossamfunn, sekulære livssynssamfunn eller religionssamfunn. De går glipp av verdifull kunnskap om bygg, tradisjoner, praksiser og møteformer og et møte med en representant for den kristne religionen. Det er her vi ser at Dnk i mangfoldssamfunnet får en opplysende rolle overfor medlemmer tilhørende minoritetskulturer.

Dnk som folkekirke har som representant for den evangelisk lutherske kristendom, en utadrettet undervisende funksjon i et mangfoldig samfunn. ${ }^{19}$ Skolen har et ansvar i form av å gi tilstrekkelig innføring i nasjonens kulturelle historie og verdibasis. Men dersom alle borgere uavhengig av religionsbakgrunn skal ha mulighet til å forstå kristendom som en levende religion, får kirken her en funksjon. Den får et ansvar overfor mangfoldssamfunnet i form av å være gode representanter i opplæring, i nestekjærlig praksis og i dialog. Dette kan beskrives som Dnk's kulturoppgave, som går videre enn å drive trosopplæring. Vi kan kalle dette å drive opplæring i kristendom, eller bidra til kristendomskunnskap i samarbeid med barnehager, skoler, arbeidsliv, kultur- og samfunnsinstitusjoner. Målet for denne opplæringen er å framstå som gode representanter for kirken for å klargjøre hva det er å tilhøre den kristne religion. Hensikten er å gi innsyn i kristendom som aktuelt fenomen, som tilskudd til lærebøkenes informasjon. Dette utfordrer samtidig kirkelig undervisning på å bli bevisst visse skiller. På den ene side når det er undervisning på allmenne premisser (som i skolen),

19 En parallell drøfting av kirkens ansvar i mangfoldssamfunnet ser vi har pågått lenge i USA, jf Seymour mf. 1984: The Church in the Education of the Public. 
med vekt på ikke-deltakende observasjon. På den andre siden når det undervises på kirkens premisser, som felles høytidsmarkering med gudstjeneste. Da er det behov for en bevissthet hos kirkens representanter til å gi barn og unge mulighet for å innta en observerende og ikke-deltakende rolle i de praksiser som er inkludert i markeringene eller gudstjenestene. ${ }^{20}$ For å skjelne mellom kirkens ulike roller bruker vi en modell med flere overlappende sirkler. Den indre sirkel illustrer de som jevnlig deltar i gudstjeneste og undervisning. Den neste sirkel er de som kommer til kirken ved livets store anledninger og høytider. Den nest største sirkelen er folkekirkemedlemmene, mens den ytterste sirkel er alle som bor i landet.

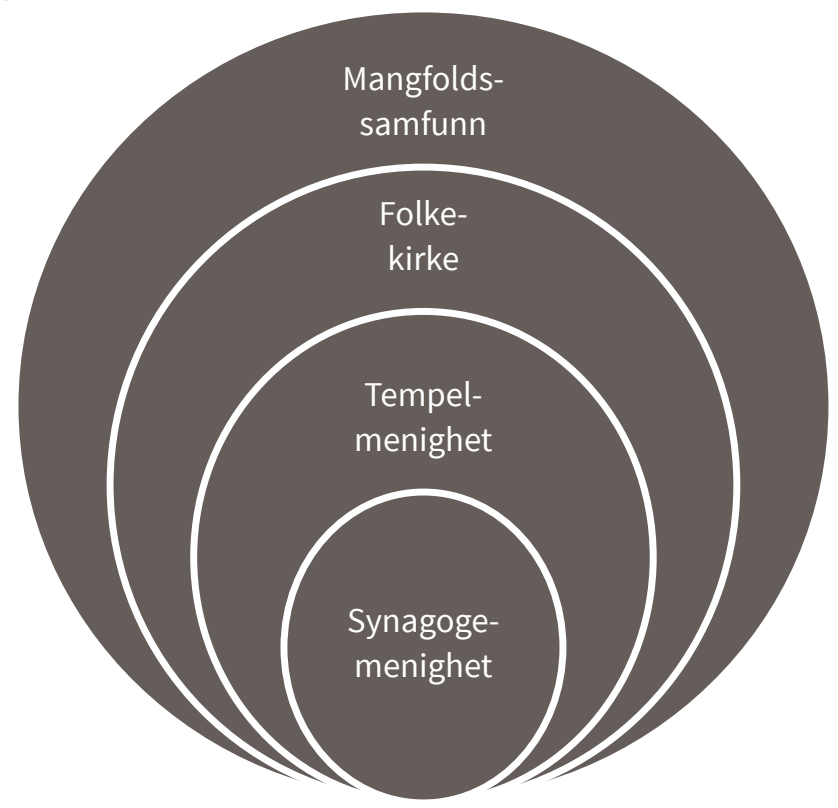

Figur: Med «synagogemenighet» mener vi de som jevnlig deltar $i$ gudstjeneste og undervisning. «Tempelmenighet» er de som kommer til kirken ved livets store anledninger og høytider, blant annet dåp. «Folkekirke» er alle medlemmer av og de med tilhørighet til Den norske kirke, og «mangfoldssamfunn» er alle som bor $i$ landet. ${ }^{21}$

Mens trosopplæring de siste årene har konsentrert seg om å nå hele tempelmenigheten (de døpte) med noen breddetiltak, så har kirkelig undervisning/ kateketikken tidligere også henvendt seg til en bredere målgruppe, både i alder og kulturell tilhørighet. I trosopplæringen ser vi at menighetens ledere oftest henvender seg til tempelmenigheten $\mathrm{i}$ håp om å få flere til å ta del i synagogemenighetens fellesskap. Da er synagogemenigheten, med jevnlig deltagelse, et ideal.

\footnotetext{
20 I skolen er deltakelse i religiøse praksiser basert på foreldres valg. Det er derfor fritaksrett fra undervisning som kan oppfattes som religiøs praksis, jf. Opplæringsloven $\$ 2$ 2-3a.

21 Se Leganger-Krogstad 2017 for nærmere utdyping av synagogemenighet og tempelmenighet.
} 
Kirkelig undervisning har tradisjonelt blitt forstått videre enn dette, blant annet inkludert det å samarbeide med barnehage og skole med et mål om å føre barn og unge inn i den kristne kultur.

Sirkelen med en folkekirke utenfor tempelmenigheten representerer alle de som tenker om kirken som et samfunnsgode og en serviceinstitusjon på linje med andre samfunnsinstitusjoner, og som skal være der når en trenger den. ${ }^{22}$ Denne kirken må ha samme geografiske dekningsgrad som andre heldekkende institusjoner, som betyr å være til stede på hver en øy og i hver dal og fjord i hele landet. Den må opprettholde et norskspråklig tilbud for alle borgere, ta ansvar for kulturbygg og nasjonalmonumenter, fungere representativt ved nasjonale markeringer og kriser, samt for Norge i internasjonale sammenhenger. Folkekirken tar også ansvar for norske borgere i utlandet: emigranter, korttidsarbeidere, sjømenn, turister og studenter. Mangfoldssamfunnet er den ytterste sirkelen og omfatter hele det norske flerreligiøse samfunn.

Ut fra teorien om dobbeltkvalifisering har alle minoritetsgruppene behov for innsikt i majoritetskulturen for å kunne fungere i det norske samfunnet. Vi må også minne om at minoritets-barn og -unge ofte tilhører minoritetskirker i Norge. Mangfoldssamfunnet har både en religionsdialogisk og en økumenisk dimensjon. Flere og flere migrantmenigheter eller språkmenigheter bruker Dnk's bygg, og det gir en god anledning til økumenisk arbeid. Vi ser at nye og annerledes undervisningsoppgaver vil oppstå eller $\emptyset \mathrm{ke}$ i omfang. Det gjelder de ikke-døpte barna i Dnk som vil $\emptyset$ nske dåp i sammenheng med trosopplæringen, andre- og tredjegenerasjons språkminoriteter som vil søke om medlemskap i Dnk, og undervisning av konvertitter. Dnk står overfor helt nye undervisningsoppgaver generelt i møte med muslimer og andre religiøse grupper i samfunnet (Børve 2007). Her har vi enda liten kunnskap, men det er et voksende forskningsfelt (Aschim, Sødal \& Hovdelien 2016).

\section{UNDERVISNING FOR ALLE DØPTE}

Trosopplæringen har skapt mye nytt, og mange barn og unge er på en ny måte og i større omfang involvert i menighetens virksomhet. Samtidig er det på landsbasis som nevnt rundt regnet bare $1 / 4$ av de døpte barna som er med i en systematisk opplæring, utenom konfirmasjonstiden. Denne opplæringen er i hovedsak knyttet til 3-4 avgrensede tiltak fra 4-12-årsalderen. Omfang av undervisningstilbudet for hele perioden $0-18$ år er $\mathrm{i}$ gjennomsnitt betydelig lavere enn det som er målsettingen på 315 timer. Den er på omtrent 200 timer. ${ }^{23}$ De harde fakta sier altså at ca. 3/4 av de døpte barna ikke făr en systematisk opp-

22 «olkekirke» brukes ofte som betegnelse på Dnk. Vi bruker her begrepet slik at det også kan omfavne folk som ikke er medlemmer i Dnk gjennom dåp, men som har tilhørighet. Det gjelder blant annet barn der bare en av foreldrene er kirkemedlemmer, eller barn i hjem med flere religioner.

23 Årsrapport 2015 Den norske kirke, s. 22. 
læring i kirken, slik det er forstått i kirkens egne planer. Disse barna får snaut én uketime med kristendomsundervisning i skolen, gitt på skolens premisser. Når dette gapet mellom ideal og virkelighet ikke er på kirkens dagsorden, kan en spørre om kirken egentlig har gitt opp visjonen om undervisning for alle døpte og slått seg til ro med at majoriteten av de døpte barna ikke får del i «en systematisk og sammenhengende opplæring»?

Om vi nå anvender perspektivet om dobbeltkvalifisering på trosopplæring $\mathrm{i}$ folkekirken, forstår vi det slik at majoritetskulturen er det som favner alle medlemmer i kirken, det at en er døpt og er medlem i kirken eller er tilhørende. Minoritetskulturen i denne sammenheng forstår vi som grupperinger eller enkeltpersoner og familier som tilhører synagogemenighet eller annet menighetsfellesskap innen rammen av Den norske kirke. Dobbeltkvalifisering betyr da et både - og, både noe fellesundervisning for alle døpte og noe som relateres til grupper innen kirken eller hjemmet. Intensjonen med en fellesundervisning for alle i folkekirken vil i tråd med tidligere utredninger være i et omfang og innhold som er tilnærmet det som var i skolen tidligere. ${ }^{24}$ I tillegg til en viss undervisning i kirkens regi, kan kirken ut fra tenkning om dobbeltkvalifisering også st $\varnothing t t e$ variasjon ut fra barn/unge og foreldres egne interesser og preferanser. Det er en slik tankegang som ligger til grunn for planens omtale av breddetiltak og samtidig samarbeid med barne- og ungdomsorganisasjoner som tilbyr sine fellesskap og kontinuerlige tiltak (Gud gir - Vi deler, s.35). Det samme kan sies om intensjonen om samarbeid med hjemmet og faddere.

Plan for trosopplering fra 2010 omtaler som en selvfølge at «dåp og opplæring har vært holdt sammen [...] i menighetens fellesskap [...] Trosopplæring er et anliggende som hjem og menighet står sammen om. [...] skjer på mandat fra foreldre/foresatte og faddere som har ønsket dåp» (Gud gir - Vi deler, s. 3). Det legges her inn forutsetninger og forventninger til de døptes foresatte, men ingen direkte forpliktelse. Trosopplæringsreformen er først og fremst en forpliktende reform på organisasjonsnivå, der menighetene blir forpliktet til å tilby en opplæring for alle døpte. Det er ikke en reform som stiller krav på individnivå, slik det før var med deltakelse i skolens kristendomsundervisning. ${ }^{25}$ Det er sannsynligvis ulike holdninger innen kirken om det kan stilles slike forpliktelser, og også hvilke virkemidler som eventuelt kan brukes for å få størst mulig samsvar mellom dåp og opplæring. På den ene siden kan en si at kirken bare er på tilbudssiden og at det er opp til foreldrene og barna hva

24 Se premissene for trosopplæringsreformen i NOU 2000:26 og Stortingsmelding nr. 7, 2002-2003. Utregning av timetall for kirkens trosopplæring er i NOU 2000:26, vedlegg 1.

25 I den første nasjonale dåpsopplæringsplanen het det blant annet at: «Dåpen innebærer et ansvar og en forpliktelse for foreldre og faddere til å sørge for at barnet får den opplæringen som dåpshandlingen forutsetter. Det betyr i praksis at barnet - ved siden av den kristne oppdragelsen i hjemmet - deltar i menighetens opplæringsprogram og skolens kristendomsundervisning.» (Kirkerådet 1992, s. 11) Skolens kristendomsundervisning var da obligatorisk for alle medlemmer i Dnk. 
en vil gjøre. ${ }^{26}$ Kirken konsentrerer seg da om det rituelle, selve dåpshandlingen, og tilrettelegger for et så godt opplæringstilbud som mulig, og kan tilby materiell og støtte til hjemmet. På den annen side kan en hevde at kirken som døper, også har ansvar for å påse at de døpte blir involvert i en opplæring, og at foreldre da må forplikte seg til å delta i en kirkelig undervisning på et visst nivå. En slik direkte sammenheng mellom dåp og opplæring blir mer tydelig når større barn, ungdommer og voksne døpes, slik det er mer vanlig i andre kulturer. Dåp som følge av opplæring eller konvertering vil Dnk sannsynligvis få langt mer erfaring med i fremtiden i et mer mangfoldig samfunn.

Når den store majoriteten som tidligere fulgte skolens kristendomsundervisning, ikke tar imot tilbudet om folkekirkens undervisning, er det naturlig å spørre hvorfor? En åpenbar grunn kan være at det har å gjøre med forskjellig kontekst og ramme for skole og kirke. Skolen er selvfølgelig for alle i samfunnet, og alle opplever en forpliktelse for barnas skolegang. Medlemskap i Dnk skaper ikke samme selvfølgelighet for kirkelig undervisning. Vi vet at de som døper sine barn, ikke er en homogen gruppe, verken når det gjelder holdning til dåpen som handling eller tanker og $\emptyset$ nsker om opplæring. Det er heller ikke lang tradisjon for systematisk opplæring i kirken, utenom konfirmasjonsundervisningen. Tradisjonen for kirkelig undervisning utenom konfirmasjonstiden kan ut fra det brede lag av medlemmer forstås som en minoritetskultur innen kirken, som en del av en organisasjon eller gruppe med særinteresser, ovenfor kalt synagogemenigheten. Foreldrene kan sitte fast i den gamle forestilling om at det å sende barna til kirke signaliserer et særlig kristent engasjement, og viser slik mangelfull forståelse for barnas behov for å få en tydeligere opplæring og tilhørighet $\mathrm{i}$ en kristen kultur, slik at de kan vite hvem de er i en flerreligiøs hverdag. Det kan være noe med «innpakningen» av undervisningen som virker for eksklusivt, at det oppfattes som noe for de aktive bevisste kristne. Det er et behov for å gjennomtenke benevnelser på trosopplæringen/dåpsopplæringen og språkbruken $\mathrm{i}$ kirkens informasjonsarbeid. Det kan også kreve for stor egeninnsats for barn og deres foreldre å måtte velge dette som ett av flere fritidstilbud.

I denne sammenheng er det vel verd å reflektere over hvorfor oppslutning om konfirmasjonsundervisningen holder seg så høyt som den gjør. Vi tenker her spesielt på to forhold. For det første har denne en lang tradisjon i vårt samfunn. For det andre avrundes denne undervisningen med et ritual. Det er en begivenhet både for den enkelte, familien og kirken. En viss konkurranse fra andre aktører (som Human-Etisk Forbund) kan også være med på å opprettholde forståelsen av konfirmasjon som et allment ritual og slik indirekte være med på å styrke oppslutning. Kanskje en skulle søke å finne frem til flere tiltak i trosopp-

26 Dette var også tankegangen når Frp i Stortinget foreslo en undersøkelse blant foreldre før en evt. vedtok en trosopplæringsreform. Men dette forslaget fikk bare deres egne stemmer. Innst. S. nr. 200 (2002-2003) 
læringen som kan ha paralleller hos også andre tros- og livssynssamfunn, og slik gjøre tiltakene mer allmenne?

I utredningen som lå til grunn for reformen (NOU 2000:26), var det lagt opp til et relativt omfattende tiltak for å inkludere alle døpte barn, men som av ulike grunner ikke er blitt realiteten så langt. Det var her lagt opp til en dåpsskole for 6 -10-åringer, ved bruk av skolens lokaler. Det var anbefalt et relativt omfattende innhold og omfang, samlet 150 timer, med en rituell avslutning. Tanken var at dette er en god «opplæringsalder». Videre var tanken at dette skulle oppfattes som allment, og være mulig å gjennomføre uten at det skulle virke for mye konkurrerende med andre fritidsaktiviteter. Dersom barn kunne være med på kirkeskolen som del av SFO-tiden, kunne dette oppfattes som noe alminnelig, på linje med kulturskole og idrett, det «alle døpte» var med på. Premisser som ble lagt inn i vedtak om reformen, gjorde imidlertid dette vanskelig. ${ }^{27}$

Når reformen nå er implementert $\mathrm{i}$ alle menigheter, er tiden inne til å tenke nytt. I fremtiden kan det være et større handlingsrom for å drøfte både barns og foreldres «rett til trosopplæring», 28 og hvilke virkemidler og metoder kirken kan bruke for i størst mulig grad å fremme intensjonen om undervisning for alle døpte.

\section{Avslutining}

Vi har løftet frem og drøftet ulike sider ved det å være undervisende menighet i Dnk, med vekt på utfordringer i mangfoldssamfunnet og at trosopplæring er for alle d $\emptyset$ pte. Vi har anvendt teorien om dobbeltkvalifisering utviklet for det flerreligiøse samfunnet på to måter: For å forstå hvilken endring av innholdet $\mathrm{i}$ kirkelig undervisning det medfører, og når det gjelder omfang og organisering. Trosopplæringsreformen har hatt som intensjon at alle døpte skal få opplæring. Tallenes tale er imidlertid tydelig. Om lag en fjerdedel av de døpte deltar før konfirmasjonstiden. Vi tenker det er vanskelig for kirken å slå seg til ro med denne situasjonen. Skolen gir kunnskap om kristendom, men ikke opplæring $i$ kristendom. Når majoriteten av de døpte ikke er med i en systematisk opplæring fra småbarnsalderen, blir barna hjemløse i religiøs forstand.

Det er også andre premisser og mål for trospplæringsreformen som vi tenker det vil være vesentlig å vie oppmerksomhet i tiden fremover, men som vi ikke har funnet plass til her. Det gjelder blant annet lokal ledelse, med samspill mellom ansatte og mellom ansatte og frivillige, og samarbeid mellom kirke og organisasjoner i lokalsamfunnet. Religionspolitiske valg og rammebetingelser for kirke og andre trossamfunn er også helt avgjørende for muligheter for den kirkelige undervisning.

\footnotetext{
27 Det gjaldt blant annet at en ikke skulle bruke skolens lokaler eller SFO-tid for trosopplæring. Se Innst. S. nr. 200 (2002-2003).

28 Dette var en del av mandatet for utredningen i NOU 2000:26, men er ikke blitt realitetsbehandlet.
} 
$\AA$ være undervisende kirke er en nødvendighet ved det å være kirke. Vi utfordrer ledere i kirke og menigheter til å gjøre strategiske valg ut fra en bevissthet om at opplæring er for alle døpte, og at den kirkelige undervisning i $\emptyset$ kende grad vil skje i et mangfoldig samfunn.

\section{LitTERATUR}

Aagedal, O., Haakedal, E., \& Kinserdal, F. 2014. Profesjonalisering og frivillighet. Trosopplaringsreformen og samarbeid mellom Den norske kirke og de kristne organisasjonene (Vol. 2014:1). Oslo: Stiftelsen Kirkeforskning.

Afdal, G. 2008. «Menigheten som lærende fellesskap? Sosiokulturell læringsteoris muligheter og begrensninger som perspektiv på kirkelig læring.» Prismet, 59(4), 227-245.

Austnaberg, Hans. 2017. «Alle støttar trusopplæring.Tverrfagleg samarbeid mellom prestar og undervisningstilsette i utvikling av trusopplæringa.» I Prismet 68 (3) s. $211-229$

Austnaberg, Hans og Erling Birkedal. 2017. «Trusopplæringa sitt potensial i utvikling av menigheten.» I Prismet 68 (3) s. 169-188

Aschim, A., Sødal, H. K., \& Hovdelien, O. (Eds.). 2016. Kristne migranter i Norden. Kristiansand: Portal forlag AS.

Birkedal, E. 2015: «Verdigrunnlaget forblir vår kristne og humanistiske arv». Utfordringer i spenningen mellom forankring og forandring. I: Røtter og vinger. Et «matpakkeseminar» $i$ Jon Lilletuns Ånd. Svein Helgesen (red.). Kristiansand: Portal forlag AS.

Birkedal, Erling og Hans Austnaberg. 2017. «Planarbeid i trosopplæring som ressurs for menigheten?» I Prismet 68 (3) s. 189-209

Birkedal, Erling. 2017. Frivillighet i trosopplæringen. I Prismet 68 (3) s. 231-241

Botvar, P. K., Haakedal, E., \& Kinserdal, F. 2013. Når porten gjøres vid : evaluering av trosopplceringens breddetiltak (Vol. 2013:2). Oslo: KIFO Stiftelsen Kirkeforskning.

Botvar, P. K., Brottveit, Å., Hoel, N., Haakedal, E., \& Schmidt, U. 2015. Avsluttet reform eller fortsatt læring og utvikling? Trosopplering som arbeidsform i menighetene (Vol. 2015:1). Oslo: KIFO, Institutt for kirke-, religions- og livssynsforskning.

Børve, K. S. 2007. Med åpne armer. Dåpsopplcering for voksne med muslimsk bakgrunn (Master i kirkelig undervisning (30 ECTS)), Det teologiske Menighetsfakultet, Oslo.

Dobson, S., Kulbrandstad, L. A., Sand, S., \& Skrefsrud, T.-A. 2015. Dobbeltkvalifisering. Perspektiver på kultur, utdanning og identitet. Bergen: Fagbokforlaget.

Dåpspraksis og dåpsopplœering i Den norske kirke: en utredning avgitt til Bispemøtet våren 1982 med Bispemøtets vedtak og studieplan for sju samvær. 1982. Oslo: IKO's Læremidler. 
Engen, T. O. 1989. Dobbeltkvalifisering og kultursammenlikning. Utkast til en oppdragelses-loereplan- og planleggingsmodell. Vallset: Oplandske bokforlag.

Engen, T. O. 1994. Integrerende sosialisering i majoritetens skole? [Oslo]: Ad Notam Gyldendal.

Evenshaug, O., Hallen, D., og Riktor, F. 1986: Barnet i våre hender. Oslo: HD-Forlaget

Holmqvist, M. 2014. The material logics of confirmation. I International Journal of Actor-Network Theory and Technological Innovation, 6(4), 26-37.

Horsfjord, H., Sørensen, T., Heiene, G., Leganger-Krogstad, H., \& Holmqvist, M. 2015. Kompetanse, utdanning og motivasjon: en kartlegging av undervisningstjenesten i Den norske kirke. Vol. MF-rapport 1:2015. D. t. menighetsfakultet (Ed.) Retrieved from http://www.mf.no/sites/mf/files/users/Dokumenter/Forskning/ Trosopplaring/kompetanse_utdanning_og_motivasjon-_en_kartlegging_av_ undervisningstjenesten_i_den_norske_kirke_2015.pdf [10 april 2017].

Innst. S. nr. 200 (2002-2003). Innstilling fra kirke-, utdannings- og forskningskomiteen om trosopplæring i en ny tid. Om reform av dåpsopplæringen i Den norske kirke.

Kirkerådet. 1992. Plan for dåpsopplaering i Den norske kirke. Oslo: Den norske kirke.

Kirkerådet. 2010. Gud gir - vi deler. Plan for trosopplæring i Den norske kirke. Oslo: Den norske kirke.

Kirkerådet. 2016. Arsrapport for Den norske kirke. https://kirken.no/globalassets/kirken. no/om-kirken/slik-styres-kirken/kirkemotet/2016/saksdokumentene/kr_mkr_ skr_aarsapport-2015.pdf [13. desember 2016].

Leganger-Krogstad, H. (2008). Religions- og livssynsdidaktikk (pp. 175-205). Bergen: Fagbokforl., cop. 2008.

Leganger-Krogstad, H. 2010. «Kristen teologi i et mulitreligiøst perspektiv.» I J.-O. Henriksen \& A. O. Søvik (Eds.), Livstolkning i skole, kultur og kirke: Festskrift til Peder Gravem (pp. 45-53). Trondheim: Tapir Akademisk.

Leganger-Krogstad, H. 2011. The religious dimension of intercultural education. Contributions to a contextual understanding. Münster: LIT-Verlag.

Leganger-Krogstad, Heid. 2017. «Trosopplæring og gudstjenester. Menighetsutvikling i dybde og bredde.» I Prismet 68 (3) s. 243-258

Mønsterplan for grunnskolen: M87. 1987. Oslo: Kirke- og undervisningsdepartementet. Aschehoug.

NOU 1995:12. 1995. Opploering i et flerkulturelt Norge. Utredning fra et utvalg oppnevnt av Kirke-, utdannings- og forskningsdepartementet. Avgitt februar 1995 Norges offentlige utredninger (tidsskrift : online)

NOU 2000: 26. 2000. «- til et åpent liv i tro og tillit». Dåpsopplæring i Den norske kirke. Fra et utvalg oppnevnt ved kongelig resolusjon av 16. juli 1999 : avgitt til Kirke-, utdannings- og forskningsdepartementet 10. oktober 2000. (8258305395). Oslo: 
Statens forvaltningstjeneste, Informasjonsforvaltning.

NOU 2007:6. 2007. Formål for framtida. Formål for barnehage og opplæering. Utredning fra et utvalg oppnevnt ved kongelig resolusjon 2. juni 2006: avgitt til Kunnskapsdepartementet 8. juni 2007. (9788258309212). Oslo: Departementenes servicesenter, Informasjonsforvaltning.

Rudge, L. 1998. «I am nothing - does it matter? A critique of current religious education policy and practice in England on behalf of the silent majority.» I British Journal of Religious Education, 20(3), 155-165.

Seymour, J.L, O'gorman, R.T, og Foster, C.R 1984: The Church in the Education of the Public. Refocusing the task of religious education. Nashville: Abingdon Press.

Wanjiru, Margaret Wangari. (2013). The role of immigrant churches in the incorporation of their participants to the broader norwegian society. (Masteravhandling $\mathrm{i} \ll$ Religion, Society and Global issues»), Det teologiske menighetsfakultet, Oslo. 